\title{
Entrepreneurship Education Must Start Before College
}

\author{
Roy Carriker (Drexel University)
}

\begin{abstract}
KEYWORDS: Entrepreneurship, Teaching Methods, student entrepreneurs, Student innovators.

While technology continues to replace human endeavor, society hasn't yet discerned how to address its impact on future workforce economic well-being. Until recently the impact has primarily been on middle- to lowerincome wage earners. But now, the historic prescription for assuring greater earnings over one's lifetime -- a college degree -- is failing for many, resulting only in underemployment and an inability to repay student loans.
\end{abstract}

The education system must address how to better prepare youth to anticipate shrinking historic career paths and find alternatives. Whether they choose a job or more career training after high school, this is a critical juncture in a person's life and students must have the information they need to make informed decisions. Giving students insights into rapidly evolving career options and the tools to be the entrepreneurs of their own lives is a critical first step.

\section{What's the Urgency?}

The US and other developed economies are struggling with gainful employment for large numbers of citizens. Abundant data points to eroding earning power for significant portions of the workforce, including even the college-educated. The facts suggest that technology is reducing the need for human beings in the workplace faster than society can figure out how to adjust to it.

According to Andrew McAfee, management theorist at MIT's Sloan School who studies these issues: "Just in the past couple of years, we've seen digital tools display skills and abilities that.....eat deeply into what we human beings do for a living"; and "Within [our lifetimes], we're going to transition into an economy that...doesn't need a lot of human workers. Managing that transition is going to be the greatest challenge that our society faces."

Some do not accept this view. For example, in a piece titled "False Alarmism: Technological Disruption and the US Labor Market, 1850-2015", Atkinson and Wu advise: "Take a deep breath, and calm down. Labor market disruption is not abnormally high; it's at an alltime low, and predictions that human labor is just one tech "unicorn" away from redundancy are likely vastly overstated, as they always have been."

Even for human labor not replaced by technology, it remains likely work within many career paths will remain unpredictable. Examples of labor market disruption abound, suggesting ever greater difficulty in finding jobs for those who lack special skills and who are more vulnerable to automation. For example, according to the Robert Wood Johnson Foundation, in 2015 nearly 5 million "disconnected youths" between the ages of 16 and 24 were neither in school nor working.

Looking at employment figures in isolation can be deceiving, since everyone needs to earn a living and if the choice is between a less desirable job and no job, people must opt for the former. Just as with any good or service, oversupply results in lower prices, or in the case of labor, lower wages for over-qualified workers.

The employment landscape has changed dramatically in just the span of a few decades. Off-shoring was rapidly followed by increasing use of temporary workers, then part-time temporary work, robotics and automation, all to lower labor costs. The result: on an inflationadjusted basis, US middle- to lower-middle income workers earn less today than three decades ago. Until recently, knowledge workers with university degrees or advanced training were safe, but now online capabilities have facilitated off-shoring their work and artificial intelligence is replacing the need for humans altogether.

\section{College Graduates are Driving Taxis}

Many recent university graduates are already experiencing a challenging job market and troubling underemployment. In polls of recent college graduates, from 41\% (April 2013 Accenture Report, Wall Street Journal January 2014, Gallup 2013) to 46\% (May 2014 Accenture Report, Federal Reserve Bank of New York Report) said they were either underemployed or didn't 
even need a degree for their current job. On an inflationadjusted basis, graduating US university students on average earn less today than they did a decade ago. It is predicted that Al will replace the solid careers now held by university-educated knowledge workers who use data and set decision rules: accountants, auditors, structural engineers and many others. And in further testament to the underemployment of university graduates, Wall Street Journal online recently reported that $15 \%$ of taxi drivers in the US have a college degree, up from less than $1 \%$ in 1970.

While admitting the issue is complex, a September 6, 2017 WSJ article "Automation's Surprise Benefit: More Jobs" reports E-commerce more than compensates for layoffs by traditional retailers, pointing to data on the employment growth in highly automated E-tail fulfillment centers versus the job losses in traditional retail outlets.

However, the evolving employment picture is more complex than these focused discussions would allow. Sears Holdings alone lost an estimated 7,048 jobs in October 2014, after it closed 63 Kmart stores, 34 Sears stores, 34 Sears Auto Centers, 1 Kmart distribution center and 1 Sears product repair facility. These closings reportedly resulted in 7,048 employee layoffs, an average of 53 layoffs per facility. In the decade leading up to January 2016, Sears had closed 166 stores while Kmart had closed 474, with an additional 42 Sears and $108 \mathrm{Kmart}$ stores closed in 2017. This translates to about 42,000 layoffs, with more closings expected next year. If the company goes bankrupt as some suggest, an additional 80,000 jobs may be lost. The closing of retail stores and chains, malls and shopping centers is expected to accelerate this trend and is sure to outweigh the jobs added by e-tailing.

Another telltale sign that traditional employment is waning is the rise of the sharing or mesh economy. One must ask: if people were truly at full employment rather than being underemployed, would college graduates work for Uber or Lyft and use their own cars to drive strangers around to earn extra income? Would they board strangers in their personal living spaces via Airbnb to earn extra funds? Might the growth and popularity of these platforms be interpreted as vast numbers of people needing to supplement their incomes?

\section{Why High School?}

Historically, in developed societies such as the US, completing a high school education has been deemed sufficient to get a job and earn a living. For those aspiring to have a "career" that offers far greater earning potential than just a "job," a college education or other advanced training was the prescription. Unfortunately, many traditional paths to securing a "good living," including a number involving university education, are slipping away.

The income-earning path chosen as a student departs high school is often a pivotal decision in his or her life, often setting a life-long trajectory. To make such a critical decision, students must have a clear picture of the accelerating changes in the potential for earning a living today and the growing uncertainty of future work. Students must have this knowledge before high school graduation.

\section{Why Entrepreneurship?}

Going forward, "entrepreneurship" should have a far broader meaning than simply starting an enterprise. Entrepreneurship needs to encompass a habit of mind and an approach to addressing challenges and risks. Because of uncertainties in how one may be able to earn a future living, it is likely many if not a majority of individuals may default to becoming the entrepreneur of their own lives -- i.e., self-employed or being more entrepreneurial in some way, never having intended to start something.

It is very easy to envision a future where many will not be traditionally employed job holders, but rather will earn a living by being a multi-tasking "company-of-one." This might mean earning money by utilizing specialized skills or knowledge directly for clients; functioning as an independent contractor doing work arranged through an intermediary agency; renting a spare bedroom via Airbnb; etc. People who do this will require the same skills as traditional entrepreneurs: presenting yourself and your ideas, effective/succinct writing, negotiation, self-branding and the basics of running a business.

So it's increasingly urgent to prepare young people for the possibility that this is how they will earn their living. High school is the most effective place to teach these realities and give students the skills they need before they start their career path. Finally, while nobody has figured out how society can deal with technology replacing human endeavor, being the "entrepreneur of one's own life" provides a mindset with a greater range 
of alternatives and skills for dealing with an uncertain future.

\section{Things Young People Should Know}

High school is a good time to prepare students for the reality that the concept of a job, i.e., earning a living, is dramatically changing. Here are some key things we should tell them to prepare them for the dramatically changing world of earning a living:

Global competition is driving business to be ever more productive to survive. In this drive, business is redefining employment -- facilitated by new technology, automation, off-shoring, the Internet, and recently, with particularly dramatic advances in information technology and artificial intelligence. In the span of just several decades typically earning a living has gone from working for a few employers over a lifetime and receiving retirement income from one or two to having many employers over a working lifetime with no meaningful accumulation of employer-provided retirement benefits. As early as 2008 , the US Bureau of Labor estimated that students joining the work force would average 10-14 employments by the age of 38 .

Continuous disruption is inevitable. Consider driverless vehicles, which are on the horizon in the next few decades. How many now making a living driving will be displaced? With the potential of $24 / 7$ availability and utilization of vehicles, will the number of vehicles manufactured and the supporting industries such as tires, accessories, accident repair, auto insurance, etc. shrink significantly? How many jobs will be lost as a result?

Prepare to be part of " a company-of-one." The US Census Bureau maintains statistics on "Non-Employer Firms," which they define as self-employed individuals operating very small unincorporated businesses, which may or may not be the owner's principal source of income. The census uses information from the IRS to track the number of such firms as well as their revenues. The number of non-employer firms has risen sharply since 2007, before the global financial crisis, and has reached 21.7 million, up nearly $41 \%$ from a decade before. Since a number of the self-employed may not be reporting revenues to the IRS, the actual number could be much greater than 21.7 million. Indeed, several years ago the Wall Street Journal estimated the number of selfemployed in the US to be approximately 40 million. If this estimate is accurate, essentially one quarter of US workers are now self-employed and could be considered entrepreneurs. This trend to greater selfemployment can already be recognized in knowledge workers working as independent contractors in consulting, IT, engineering, accounting, law specialties, etc. Outsourcing reinforces this trend, and firms are finding that hiring independent expertise as needed is less expensive than hiring an in-house staff, and helps them tap a greater level of expertise.

Unrelenting trends will continue to reduce jobs in developed economies. Global outsourcing has become commonplace and is growing, even down to contracting individuals with highly specific skills on a project-by-project basis. Technology will have an even more profound effect on jobs of the future, replacing human endeavor regardless of geography. We have already seen that automation and robotics are replacing humans in manufacturing, distribution, and other fields, actually resulting in a higher level of quality and reliability. And now we are seeing information technology and artificial intelligence replacing knowledge workers with college degrees.

\section{Learn to Be Entrepreneurial}

Along with understanding the above realities, having the confidence to become entrepreneurial will help students be more successful in this future workplace. They'll be far better equipped to work for themselves or start a company that might employ others.

Students need a basic understanding of entrepreneurship and the personal skills they'll need to be self-employed. This understanding goes beyond teaching them business basics and skills; it also means helping them gain the right mindset.

Hart Research Associates recently released the results of a survey conducted on behalf of The Association of American Colleges \& Universities. Besides a specific major, the six most important higher education learning outcomes were:

- The ability to effectively communicate orally

- The ability to work effectively with others in teams

- The ability to effectively communicate in writing

- Ethical judgment and decision making

- Critical thinking and analytical reasoning skills

- The ability to apply knowledge and skills to realworld settings 
These outcomes mirror the skills needed for entrepreneurial success, and support the notion that specific knowledge combined with entrepreneurial skills is a winning combination.

\section{Conclusion}

The concept of having a job and working for one or several firms over one's lifetime is rapidly coming to a close. Those earning a living in the decades ahead will work in a landscape that will seem alien to their parents and grandparents. In fact, as technology advances, a major societal issue is: what jobs will be left for humans? No simple solution exists to the growing problem of unemployment and underemployment -among college graduates and individuals in general.

A starting point is to create high school "Life Strategies" courses covering:

- The rapidly changing realities students will face in earning an income over their working life times

- An awareness of the value of a basic entrepreneurial skill set, including oral and video presentation, effective written communication, case method problem solving, negotiation, leadership/team building, personal finance and personal branding

- The elementary concepts of entrepreneurship one would need for even self-employment

All these elements will help students be the entrepreneurs of their own lives and improve their chances of successfully negotiating future uncertainties in earning a satisfactory living in the five or six decades they will likely have to work. Further, the above skill set is valuable even for those fortunate enough to get a traditional full-time job with a more certain career path.

No matter how we perceive technology's impact on human jobs, we should all agree that students need:

- Better information about future employment realities

- Better preparation for career path decisions

- An entrepreneurial mindset and tools

Due to the rapidly evolving world of work, students need these skills earlier than ever before. High school is not too early to start.

\section{References}

WNYC May 17, 2017, "New Report Warns of Growing Number of Disconnected Youth," http://www.wnyc.org/story/confronting-economic-andsocial-realities-americas-disconnected-youth/

Wall Street Journal, Sept. 6, 2017, “Automation's Surprise Benefit: More Jobs,"

Information Technology and Innovation Foundation, May 8, 2017, "False Alarmism: Technological disruption and the US labor market, 1850-2015"

Wall Street Journal, June 4, 2017, "The Diminishing Returns of a College Degree," https://www.wsj.com/articles/the-diminishing-returns-ofa-college-degree-1496605241

US Census Bureau, "Non-employer statistics," (https://www.census.gov/programs-

surveys/nonemployer-statistics.html) May 25, 2017

Gendron, George, "Entrepreneurship Programs Should nurture Companies of One," (https://eiexchange.com/content/39-entrepreneurshipprograms-should-nurture-compani) Entrepreneurship and Innovation Exchange, November 2014

Hart Research Associates. 2015. Falling Short? College Learning and Career Success. Washington, DC: Association of American Colleges and Universities. 